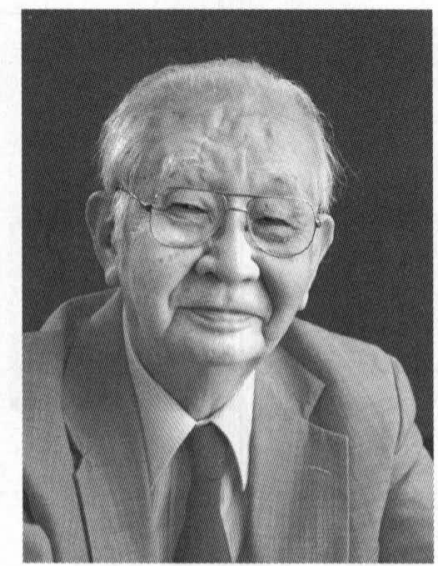

中西香爾氏

\title{
文化勲章を受章された 中西香爾先生
}

\section{慶応義塾大学名誉教授 山村庄亮}

この度, コロンビア大学名誉教授の中西香爾先生が, 有機化学, 特に天然物有機化学・生物有機化学の分野で 顕著な業績を上げられたことにより日本文化の向上に大 きく貢献されたとして文化勲章を受章されました。ご受 章を，本協会の会員として，また先生から天然物化学の おもしろさ，素晴らしさを手にとってお教えいただきま した弟子の一人として，心よりお慶び申し上げます。

中西先生は香港でお生まれになり, 幼少期を海外で過 ごされ，甲南高等学校(旧制)を経て 1947 年名古屋大学 理学部化学科(故江上不二夫教授)をご卒業になり，その 後ハーバード大学(L. Fieser 教授)へ留学, 1954 年理学 博士 (故平田義正教授), 1955 年名古屋大学理学部助教 授, 1958 年 32 歳の若さで東京教育大学理学部教授, さ らに 1963 年東北大学理学部教授を経て，1969 年コロン ビア大学化学教室教授, 2007 年同大学名誉教授となら れ, その間, ケニア国際昆虫生理生態研究所長やサント リー生物有機科学研究所長も務められました。また，そ の間, 薰陶を受けた学生・博士研究員は 450 名を超し, 150 名は大学で研究・教育に当たっています。

先生は, これまで動・植物, 微生物から 200 を超す生 物活性天然物を単離・構造決定され，さらにこれらの小 分子と標的高分子(タンパク質, DNA ど) との相互作 用, 活性発現機構の解明など先導的な業績を上げられま した。例えば, 植物からの昆虫脱皮ホルモンの発見(朝 日文化賞, 1968 年), イチョウの成分ギンコライド，赤 潮の神経毒ブレベトキシン, スズメ蜂毒のフイラントト キシン等, 先生のご研究の一部ですが，それぞれの分野 で大きなインパクトを与えています。また先生のライフ ワークとも言える視覚の分子機構については, 視物質レ チナールとその受容タンパク質オプシンとの相互作用と それらの生体内での Gタンパク質を介した動きを初め て明らかにされ，この分野での先導的業績を上げられま した。また，老化により盲目となる原因の一つとして蛍 光色素(A 2-E)の生成によることも明らかにされました (キングファイサル国際賞, 2003 年)。
一方，1950 年，機器分析の草創期に，先生は IR スペ クトルの重要性をいち早く認識され，天然物の構造研究 にIRを用いられ，著書「赤外線吸収スペクトル：定性 と演習」は英語版も出版され，国内外で広く読まれてい ます。さらに, 先生は, 複雑な天然分子(ギンコライド) の構造決定に初めて NOE (Nuclear Overhauser Effect) を使われ，その有用性を世界に先駆けて実証され，また 1969 年から歳月をかけて，CD スペクトルを用いた汎用 性のある有機分子の絶対配置決定法(The exciton chirality circular dichroic method)を確立されました。

このように, 卓越した業績により, 先生は国内外で 30 を超す学術賞を受けておられます。日本では，朝日 文化賞, 日本化学会賞, 学士院賞・恩賜賞を, また 1999 年には文化功労者として顕彰, 米国では, アメリ カ化学会賞 (A.C. Cope Award), 全米科学アカデミー化 学賞，ロバート・ウェルチ賞など，またキングファイサ ル国際賞(アラブのノーベル賞)やテトラヘドロン賞など を受けておられます。特に，1996 年，日米両化学会の 共同事業としてナカニシ・プライズが創設され，偶数年 は日本，奇数年は米国において，ナカニシ・シンポジウ ムの開催を伴って授与されています。なお，最初の受賞 者は, 故平田義正先生 (学士院賞, 文化功労者)で, 米国 側は，F. H. Westheimer ハーバード大学名誉教授です。 本事業が太平洋に架ける橋として，これからも益々発展 することを心より期待しています。

中西先生は, 絶えず日本の化学の発展に気を配られ, 大学の研究体制などについて積極的に提言され，また日 本発の国際誌 The Chemical Record の編集長をされて おられます。

ご退職後も，先生は，これまでと変わらず，奥様の手 弁当を研究室に持参され，「イチョウのギンコライドが 脳の海馬に直接作用する」ことを証明される等，研究に 明け暮れておられます。これから先も，先生には健康に ご留意いただき，天然物有機化学・生物有機化学の発展 のために，後進のご指導を心よりお願い申し上げます。 